\title{
Review
}

Dev Neurosci 2009;31:23-35

DOI: $\underline{10.1159 / 000207491}$
Received: March 24, 2008

Accepted after revision: October 20, 2008

Published online: April 17, 2009

\section{Third Pathophysiology of Prenatal Cocaine Exposure}

\author{
Barry M. Lester James F. Padbury \\ Warren Alpert Medical School of Brown University, Women and Infants' Hospital of Rhode Island, Providence, R.I., USA
}

\author{
Key Words \\ In utero cocaine exposure · Fetal programming • \\ Neuroendocrine $\cdot$ Stress $\cdot$ Behavioral outcome
}

\begin{abstract}
The pathophysiology of the effects of cocaine on fetal development has been described along 2 major pathways: neurochemical effects and vasoconstrictive effects. Following a summary of these effects, we suggest a 'third pathophysiology' in which altered fetal programming affects the acute and long-term adverse effects of in utero cocaine exposure. We describe how cocaine as a stressor alters the expression of key candidate genes, increasing exposure to catecholamines and fetal cortisol-altering neuroendocrine (hypothalamic-pituitary-adrenal axis) activity, leading to infant behavioral dysregulation, poor behavioral control and emotion regulation during childhood and phenotypes that confer vulnerability to substance use in adolescence. This model is discussed in relation to follow-up studies of the effects of in utero cocaine exposure and maturational changes in brain development.

Copyright $\odot 2009$ S. Karger AG, Basel
\end{abstract}

The growing understanding that addiction is a brain disease expressed as a form of compulsive behavior [1] leads to questions about the possible origins of addiction due to factors such as prenatal drug exposure. Cocaine readily crosses the placenta through simple diffusion to enter embryonic circulation and affect the developing fe- tus [2]. The pathophysiology of the effects of cocaine on fetal development has been described along 2 major pathways. One pathway is the direct effects of cocaine on neurotransmitter turnover in the brain and peripheral nervous system sites. The second pathway is through indirect vasoconstrictive effects. Here, we propose a third pathophysiological mechanism in which cocaine acts as an intrauterine stressor that alters fetal programming, disrupting the fetal-placental neuroendocrine microenvironment, changing the genetic programming of fetalplacental development. We first summarize the wellknown evidence supporting the neurochemical and vasoconstrictive mechanisms. Then we present evidence for our model of the 'third pathophysiology' of cocaine, and suggest how altered fetal programming contributes to the acute and long-term adverse effects of in utero cocaine exposure.

\section{The First Pathophysiology: Neurochemical Mechanisms}

The pathophysiology of the effects of cocaine on fetal development is most often attributed to neurochemical mechanisms. Cocaine acts primarily at the presynaptic level to block reuptake of the monoaminergic neurotransmitters dopamine, norepinephrine and serotonin $[3,4]$ by specific presynaptic plasma membrane transporters [5]. These transporters are expressed in discrete pathways of the central nervous system on postganglionic sympathetic neurons and in the adrenal medulla. These phar-

\section{KARGER \\ Fax +4161306 1234 \\ E-Mail karger@karger.ch}

www.karger.com (c) 2009 S. Karger AG, Basel

0378-5866/09/0312-0023\$26.00/0

Accessible online at:

www.karger.com/dne
Barry M. Lester, $\mathrm{PhD}$

Women and Infants' Hospital of Rhode Island

101 Dudley Street

Providence, RI 02905 (USA)

Tel. +1 401453 7640, Fax +1 401453 7646, E-Mail Barry_Lester@Brown.edu 
macologic actions lead to elevated circulating catecholamine levels and exaggerated sympathetic responses including hypertension, tachycardia, vasoconstriction, agitation, euphoria and excitation. These effects are particularly profound in the fetus, in which elevated sympathetic tone has been demonstrated [6-9]. Part of the high abuse potential of cocaine is due to increased dopaminergic activity in pathways involved in mood, pleasure and reward [10]. Tolerance is associated with escalating doses of the ingested drug. However, sensitization to the effects of repeated cocaine administration may also be seen, resulting in increased responses to equivalent doses. This is particularly true for the behavioral effects of cocaine $[11,12]$. The mechanism for behavioral sensitization is due to an increase in extracellular neurotransmitter concentrations $[12,13]$, alteration in $\mathrm{G}$ protein-coupled neurotransmitter receptors [14] and alteration in the plasma membrane transporter expression $[15,16]$. Although cocaine also interacts with other neurotransmitters (neuropeptides, GABA and glutamate receptors), less is known about these effects [17-20]. Cocaine affects neuronal formation, proliferation and early connectivity [21-23], and disrupts neuronal migration and resulting cortical architecture [24-27]. Cocaine also affects the expression of transcription factors (immediate early genes) along dopaminergic $[28,29]$ and serotonergic pathways [30].

It is important to note that in contrast to the effects of cocaine on the adult brain, which result in deformation of the developed brain, fetal effects are more likely to produce malformation of the developing brain, in which the brain is prevented from forming normally [31]. The effects of exposure during the first half of gestation will impact upon processes related to cytogenesis and histogenesis, whereas effects during the second half of gestation are related to brain growth and differentiation. In vitro studies of human fetal brain-derived neural precursor cells treated with cocaine showed marked inhibition of proliferation, migratory response and cell differentiation. These results point towards the existence of several molecular and cellular mechanisms triggered by exposure to cocaine that could adversely affect the fetal brain, with long-term implications.

\section{The Second Pathophysiology: Vasoconstrictive Mechanisms}

The effects of cocaine on fetal development have also been attributed to indirect vasoconstrictive mechanisms. Physiological derangements in utero result in increased plasma catecholamine concentrations and marked secondary effects [6]. Redistribution of blood flow during fetal stress is secondary to increased sympathoadrenal system activity and results in exaggerated elevations in plasma catecholamine levels [32, 33]. This cascade of events is important in the pathophysiology of pregnancy disorders associated with placental dysfunction [34, 35], impaired placental blood flow and is a cause of intrauterine growth restriction [36-38]. This also explains the adverse effects on the fetus of uptake inhibitors, such as cocaine and amphetamines, which block catecholamine transport $[6,39]$. Their effect on placental vascular function is to decrease placental blood flow, reducing the supply of oxygen and nutrients to the fetus. Fetal hypoxemia and possibly ischemic injury can compromise brain development. Blood flow to the developing brain can also be reduced by cocaine-related noradrenergic effects on the developing fetal vasculature $[40,41]$. Norepinephrine, and particularly the monoamine serotonin $(5-\mathrm{HT})$, exert vasoconstrictive effects on the umbilical vein; thereby, reducing blood flow from the placenta to the fetus [42, 43]. Furthermore, the vascular response to $5-\mathrm{HT}$ is potentiated by uptake inhibition $[44,45]$. As the umbilical cord is not innervated, the placental mechanisms for catecholamine uptake described below are protecting the umbilical-placental circulation from deleterious effects of these neurotransmitters [46, 47].

Regulation of the placental mechanisms for catecholamine uptake should not be viewed solely in the context of protecting the fetus from exaggerated elevations in catecholamines and/or serotonin. Endogenous catecholamines are critical to embryological development, fetal and neonatal growth, and survival. This conclusion is supported by studies in mice in which the gene for either tyrosine hydroxylase $[48,49]$ or dopamine $\beta$-hydroxylase $[50,51]$ has been disrupted. The majority of fetuses homozygous for the disruption of either gene die during embryonic development. 5-HT is also important at critical stages of development [52]; it is present in early embryos and has been suggested to be maternal in origin [53]. However, embryos grown in the presence of high concentrations of 5-HT or 5-HT-uptake inhibitors develop cranio-facial and cardiac abnormalities of the 3rd-5th branchial arches [54]. Similar abnormalities have been seen in mouse, rat and chick embryos [55]. Thus, there are highly regulated mechanisms controlling the concentration of intrauterine biogenic amines that are central to fetal growth and development. Maternal administration of uptake inhibitors in early to mid-gestation during placentation and embryogenesis leads to a high incidence of 
fetal/placental resorption $[56,57]$. In survivors, there is a significant reduction in birth weight and delay in maturational milestones (ear opening) [56]. In addition, vasoconstriction at the uteroplacental complex coupled with anorexic effects of cocaine could also explain the increase in intrauterine growth retardation in cocaine-exposed infants that we [58], as well as others, have reported. Thus, the capacity for placental biogenic amine uptake and/or transport has a significant impact on intrauterine growth and development.

\section{The Third Pathophysiology of Cocaine: Fetal Programming}

In addition to the neurochemical and vasoconstrictive effects of cocaine on fetal development described above, cocaine may also act as an intrauterine stressor that alters fetal programming. By stressor, we mean a challenge that alters the internal milieu (homeostasis) of the organism. As a result of cocaine as a stressor, the fetal-placental neuroendocrine microenvironment and the genetic programming of fetal-placental development are disrupted. Increasing evidence from preclinical, prospective clinical and epidemiological studies suggest that, at least in the case of disease, early development does have echoes throughout life [59-61]. The literature on the influence of prenatal stress on the offspring suggests that many biological factors acting during prenatal life are associated not only with the development of common adult cardiovascular and metabolic disorders, but also with neurobehavioral abnormalities [62-72] and behavioral disorders [73-76]. Originally known as the 'Barker hypothesis', these findings have given rise to the concept of 'fetal origins of adult disease' or the 'developmental origins of health and disease'. There are few settings in which geneenvironment interactions are more profound, critical windows are of a narrower duration, and the latency to onset of effect is shorter than the influence of an adverse intrauterine environment on neuroendocrine and neurobehavioral functioning in the newborn. The so-called Barker hypothesis has undergone several modifications to include adaptation to the postnatal environment [60] but has not, to our knowledge, been applied to the study of the effects of in utero exposure to drugs such as cocaine. We also show the application of 'fetal origins' beyond cardiovascular and metabolic consequences to neurobehavior in the developing child.

Although original studies related low birth weight to adult disease, it is generally accepted that low birth weight per se is not at the heart of these disorders, but that there are common factors that influence intrauterine growth as well as adult physiological systems [61]. The 'fetal origins' observations are due, in part, to environmental factors acting early in life that affect developing systems, altering structure, function and probably behavioral expression. It has been suggested that the biological purpose of this 'programming' is to alter the set points or 'hard-wire' physiological systems to prepare the fetus for optimal adaptation to the postnatal environmental. Responses of the fetus to an adverse intrauterine environment, such as cocaine, may be developmentally disruptive with no long-term adaptive value, although the fetus may make homeostatic adjustments that confer immediate survival advantage.

Stress hormones, such as catecholamines and glucocorticoids, can alter regulation of the neuroendocrine environment by acting on the hypothalamic-pituitary-adrenal (HPA) axis which results in an altered set point for physiologic, metabolic and behavioral outcomes [77]. Because they are an important feature of the stress response, glucocorticoids have become prominent candidates as mediators of the effects of 'programming'.

The brain is particularly sensitive to prenatal programming, including effects on the HPA axis. Pregnant dams exposed to stress show increased adrenocorticotropic hormone and CORT [61, 78, 79]. Prenatal stress also increases CORT and adrenocorticotropic hormone levels in adult offspring $[60,61,75,77]$. The effect of prenatal stress on adult hippocampal corticosteroid receptor density [76, 80-83] may have implications for emotional reactivity. Prenatally stressed rats have a high degree of 'emotionality' [84], indicated by decreased locomotion and increased defecation [84-87]. They also show less play [88], more defensive freezing [89], less movement in an activity wheel [90] and increased vocalizations [79]. Prenatal stress affects cognitive abilities including operant discrimination [91], reversal task in a water maze [92, 93] and memory [94]. In other animal studies, maternal stress during pregnancy results in offspring that are more irritable, anxious and difficult to control [61, 95-98].

Brain neurotransmitter systems and glucocorticoids interact to modulate both behavior and HPA activity [99]. Disturbances in HPA regulation and brain monoamine levels have been associated with affective and anxiety disorders in humans [100-103]. Also, in human studies, poor health outcomes have been related to prenatal stress, including low birth weight, preterm birth and intrauterine growth retardation [104, 105]. Moderate to severe stressful life during mid-gestation was related to birth 
Fig. 1. Effects of in utero cocaine exposure on placental genes affecting neuroendocrine function and behavioral development.

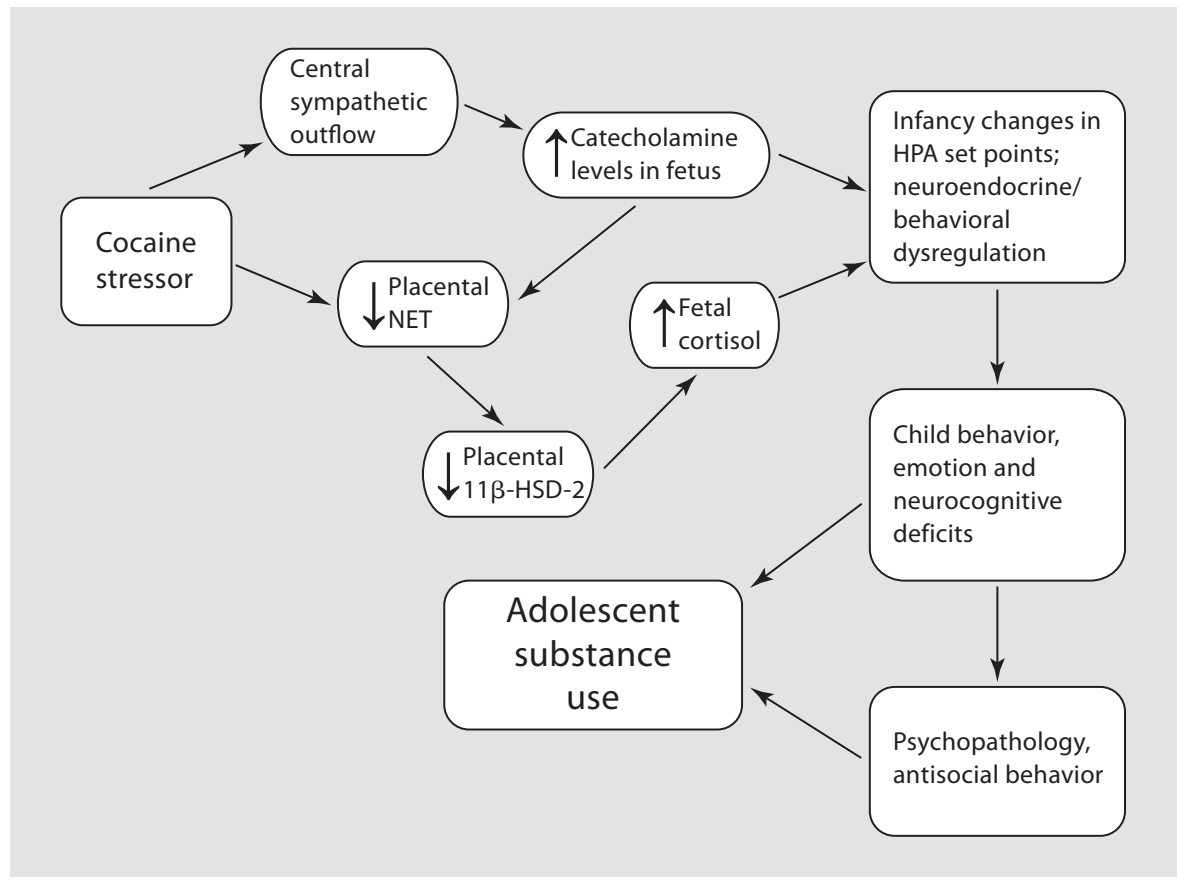

weight and small head circumference, suggesting a specific effect on the brain [106]. Maternal first-trimester exposure to the stress of war has also been associated with an increased risk of the offspring developing schizophrenia in adult life [107]. Similar to the 'emotionality' reported in animal studies, human infants exposed to stress in utero show high reactivity, activity and irritability [108110]. Psychological and behavioral abnormalities have also been reported in children exposed to prenatal stress [111-113], including learning and behavior problems [114]. The effect of prolonged exposure to chronic stress, or allostatic load [115], is the cost of wear and tear on the body produced by the repeated activation of biological stress response systems. This prolonged activation of the neuroendocrine stress axes has also been related to physical disease and behavioral disorder [116].

We suggest that stress, specifically stress-induced changes in the intrauterine environment, could lead to enduring developmental and behavioral alterations in children with prenatal drug exposure. The model that we propose (fig. 1) shows effects of an adverse intrauterine environment (cocaine) on catecholamines and glucocorticoids. As a stressor, cocaine programs the HPA axis as well as behavior due, in part, to plasticity of brain monoamine systems. Specifically, cocaine as a stressor alters the expression of key candidate genes and gene networks important to placental function in late gestation. We fo- cus on the norepinephrine transporter (NET) [117], a steroid metabolic enzyme (11 $\beta$-HSD-2) and placental gene networks.

Placental NET and $11 \beta-H S D-2$ are pivotal placental genes that program the intrauterine neuroendocrine environment during development. They protect the fetus from excess catecholamines and glucocorticoids, which have harmful effects on the fetus [118]. 11ß-HSD-2 in particular converts maternal cortisol to inert cortisone protecting the developing fetus from exposure to maternal cortisol [119]. Lower placental $11 \beta$-HSD-2 activity is associated with smaller fetuses in rats [120] and humans [121-124]. Mutations of $11 \beta-H S D-2$ are also associated with low birth weight in human infants [125] and increased fetal cortisol levels are associated with intrauterine growth retardation [126]. 11 $\beta$-HSD-2 modulates the programming effects of prenatal glucocorticoid exposure $[127,128]$. The HPA axis is highly sensitive to the effects of glucocorticoids on perinatal programming [61, 129131]. High levels of maternal glucocorticoids have been shown to disrupt intrauterine growth, postnatal HPA axis function and neurobehavioral outcome. Placental expression of this key enzyme is potently downregulated at the RNA, protein and functional levels by norepinephrine, which is in turn regulated by NET [132]. Downregulation of NET has been noted by ourselves and others in association with an adverse intrauterine environment, 


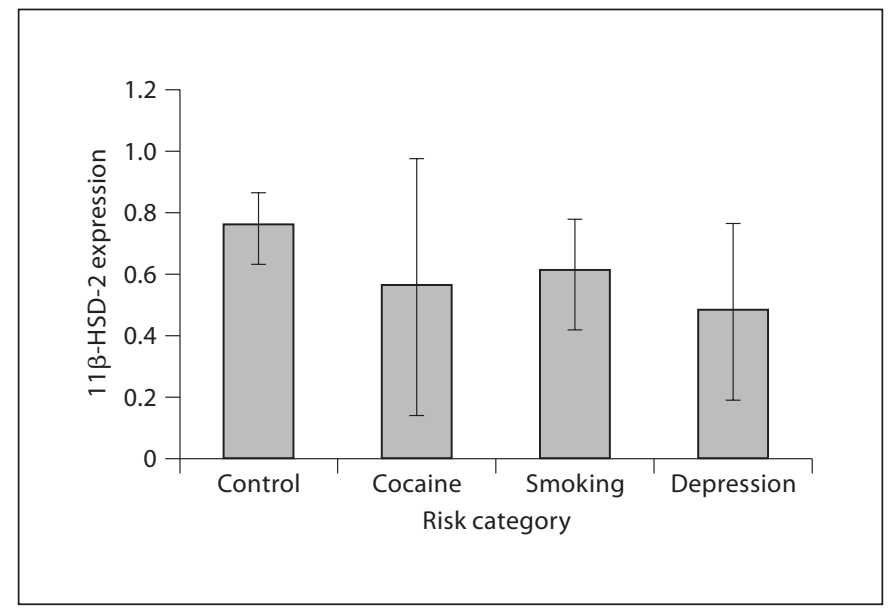

Fig. 2. Mean $11 \beta-H S D-2$ expression within main risk groups.

maternal/placental disorders such as preeclampsia, and exposure to drugs including cocaine and nicotine [133, 134]. Reduced placental NET expression from cocaine exposure may lead to increased circulating catecholamines, downregulation of $11 \beta-H S D-2$ and chronic fetal hypercortisolism, leading to altered neuroendocrine (HPA axis) activity and dysregulated neurobehavioral functioning. Because catecholamines are released during stress, this may be a mechanism linking prenatal stress with altered fetal development mediated by effects on $11 \beta$-HSD-2. Preliminary findings in figure 2 show decreased $11 \beta-H S D-2$ expression in mothers who used cocaine $(n=4)$, cigarettes $(n=4)$ or were depressed $(n=3)$ compared with 17 controls.

The altered expression of these 2 key candidate genes is likely associated with changes in networks of genes involved in critical placental functions which maintain physiological homeostasis in utero and otherwise promote intrauterine growth, development and preparation for postnatal life. Preliminary findings in figure 3 suggest that these changes in placental gene expression are associated with methylation of placental genomic DNA, particularly in promoter regions.

These findings are based on the same group of subjects with pregnancies complicated by cocaine, nicotine and depression and controls shown in figure 2. The relative incorporation of cytosine used to measure methylation was comparable in promoter and genomic DNA in the cocaine- and nicotine-exposed subjects, suggesting hypermethylation of the promoter regions of DNA that con-

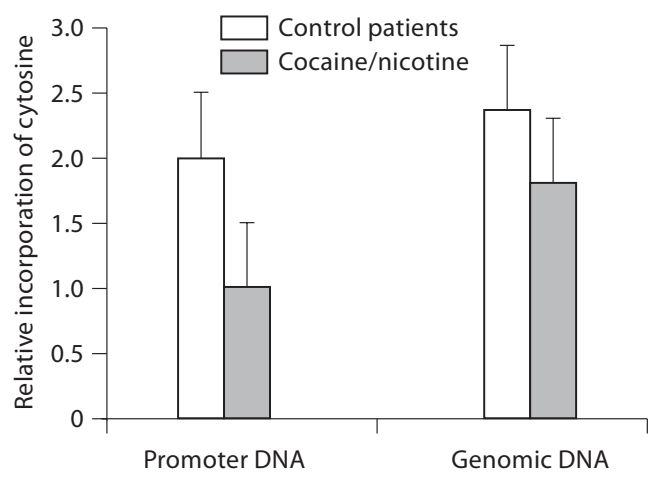

Fig. 3. Relative cytosine incorporation suggests hypermethylation of DNA in placentas from cocaine/nicotine-exposed individuals.

tain CpG islands. This hypermethylation of DNA suggests gene silencing related to in utero cocaine and/or nicotine exposure. Inheritance or persistence of these epigenetic modifications is referred to as epigenetic reprogramming. There is significant interest in modifications of DNA as one of the ways that 'adaptation to the environment' takes place mechanistically. Complex processes such as the development of memory are now being attributed to chromatin remodeling, epigenetic modifications of DNA and lasting alterations in gene expression [135]. Drugs of abuse induce 'adaptations' in brain regions. This may occur through alterations in gene expression, altered chromatin remodeling, as well as alterations in the number and projections of neurons in specific regions. Recently, cocaine was shown to induce neuroadaptations through altered gene expression [136]. Histone modifications of the $c$-fos promoter were seen in the striatum following short-term exposure to cocaine. This change was not permanent. In contrast, chronic cocaine administration was associated with alterations in the $B D N F$ and $C d k 5$ promoters [136]. It is becoming widely accepted that chromatin remodeling is an important regulatory mechanism underlying gene-environment interactions, learning and drug-induced neural and behavioral plasticity. Increased methylation of the glucocorticoid receptor and altered salivary cortisol responses to a stress paradigm has been seen following prenatal exposure to increased third-trimester maternal depressed/anxious mood [137]. Similar alterations in DNA methylation and histone acetylation are seen following intrauterine growth 
restriction [138]. It is thus likely that altered expression of these key candidate genes and associated changes in networks of genes involved in placental function follow intrauterine exposure to stress, cocaine and/or nicotine. Some of these changes may lead to permanent 'epigenetic' alterations in placental gene expression through DNA methylation and chromatin remodeling. Because of the unique nature of the intrauterine development, these observations suggest mechanisms whereby an altered placental environment can have effects on neurodevelopmental outcome.

\section{Behavioral Dysregulation}

In the model (fig. 1), the term behavioral dysregulation refers to the behavioral expression of deviations from normative biological processes in adverse environments. Behavioral dysregulation can begin in utero, and is proposed to be a dynamic developmental process as alterations in the quality of the environment (prenatal and postnatal) modify behavioral expression. Behavioral dysregulation is evidenced during infancy as neurobehavioral and neuroendocrine disorganization. During childhood, indicators of behavioral dysregulation reflect a deficient capacity to control behavior and regulate emotion commensurate with situational demands that have relevance for adaptation to environmental elements and substance use in adolescents. These phenotypes are important because they appear to be prognostic indicators for substance use [139]; the earlier a drug is used, the greater the likelihood of its abuse during adolescence and adulthood [140, 141]. These phenotypes reflect major domains of psychological function, cognition, affect and behavior, and include: impulsivity, reactive aggression, sensation seeking, excessive risk taking $[142,143]$, irritability, negative affect, difficult temperament [144-146], conduct disorder, attention-deficit hyperactivity disorder, oppositional defiant disorder, anxiety, depression [147] and impaired executive function [148-150]. This collection of disturbances in emotion regulation and behavior control is included in the construct of neurobehavioral disinhibition, and is thought to reflect disturbances in the prefrontal cortex [151] as well as other brain regions.

Disruption of neuroendocrine homeostasis in utero by cocaine can be observed at birth and lead to lasting behavioral dysregulation that increases vulnerability to substance use resulting in early-onset substance use in adolescents. The understanding that addiction is a developmental disease means that it is critical to consider the influence of specific developmental periods [152]. In addition to fetal development, we know that brain develop- ment continues well beyond childhood and adolescence $[153,154]$. The 'immaturity' or abnormal development of the adolescent brain may be related to risk taking behavior including substance use.

Extensive maturational changes that occur in brain development in adolescence may confer vulnerability to substance use through disruption to the HPA system $[155,156]$. Maturation of high-order association cortices, including changes in the prefrontal cortex, occurs later than low-order sensory cortices during late adolescence [157]. The frontal cortex has been shown to be disrupted in youths at high risk of substance use onset in neurophysiological $[158,159]$ and functional neuroimaging (fMRI) [160] studies. These high-risk youths show deficits in affect modulation, behavior control and executive function processes thought to reflect a neuromaturational disturbance subserved by neural systems in the anterior cerebral cortex [142, 161-163]. Stress reactivity is related to pubertal development and brain regions such as the hippocampus, prefrontal cortex and amygdala that are highly sensitive to stress hormones and regulate emotionality, and continue to mature during the peripubertal period [164]. Glucocorticoid receptors are present in both subcortical (paraventricular nucleus and other hypothalamic nuclei, the hippocampus and parahippocampal gyrus) and cortical structures, and, within cortical regions, the prefrontal cortex demonstrates preferential expression of glucocorticoid receptors [99, 165-167]. The distribution of glucocorticoid receptors in the primate brain are more closely related to the human brain in terms of neocortical development $[168,169]$, and nonhuman primate studies suggest that the behavioral effects of prenatal cocaine exposure may not be manifested until later in development [170, 171]. Chronic exposure to stress or allostatic load leads to atrophy and impaired neuronal function in the hippocampus and medial prefrontal cortex [172-174], regions that are responsible for executive function and adaptation to stress. Cocaine-related 'fetal programming' could have long-term effects on HPA axis activity, resulting in a physiological endophenotype of cortisol reactivity that could be a harbinger of substance use.

\section{Understanding Other Findings}

This view of cocaine as affecting fetal programming is different from the teratological view of cocaine as a toxin. There is a substantial literature on the effects of cortisol on children [175], including a few findings on infants with prenatal cocaine exposure [176-178]. The view of cocaine-induced effects as 'reprogramming' that alters 
the developmental plan may be useful for understanding the contemporary literature on the effects of prenatal cocaine exposure on behavioral development in children. Preclinical studies suggest effects of prenatal cocaine exposure on the developing monoaminergic system, resulting in both structural and functional changes to circuitry subserving functions such as arousal, regulation and reactivity $[179,180]$. Human infant studies show similar, although more generalized cocaine effects. We have shown effects of prenatal cocaine exposure on arousal, hypertonicity and excitability, and acoustic cry characteristics [181], auditory brain response [182], motor development [183], parenting stress [184], mother-infant interaction [185] and attachment [182, 186]. Others have reported difficulties in arousal regulation, greater excitability, poor state regulation, more rapid changes in arousal with stimulation, and increased arousal from sleep and physiological lability [187-193]. Cocaine-exposed infants have shown altered salivary cortisol in response to noninvasive (neurobehavioral exam) and invasive (heel stick) challenges [176], as well as decreased salivary cortisol levels at baseline compared to controls [177]. An additional study showed higher urinary cortisol levels in premature cocaine-exposed infants [178]. Alterations in HPA stress responses may be a mechanism/ marker underlying long-term behavioral and emotional disorders $[194,195]$.

\section{Follow-Up Studies}

Follow-up studies of children with prenatal cocaine exposure include children through age 15 years. Cocaineexposed children show deficits in intelligence [196-201], language $[200,202-206]$ and component academic skills, including poor sustained attention, visual-motor integration and visuospatial memory, more disorganization, impairment in procedural learning and less abstract thinking $[196,198,207-213]$. They are at risk of developing a learning disability [214], and more likely to be referred for special education services in school by age 7 years [215]. Problem behavior as well as externalizing and internalizing behaviors have been reported in cocaine-exposed children up to 7 years [211, 212, 216-219]. Effects on impulse control and attention were reported in 10-year-olds [220]. Although these effects are not consistent across studies [221-223], there is mounting evidence relating in utero cocaine exposure to phenotypes implicated in substance use. There are a few quantitative neuroimaging studies using diffusion tensor imaging [224], volumetric MRI [225-227], fMRI [228, 229], cerebral blood flow [230] and magnetic resonance spectroscopy [231] that are starting to show findings related to prenatal cocaine exposure that support long-term effects on brain structure and function.

It has been well documented that the effects of prenatal cocaine exposure need to be understood in the context of the interaction(s) between drug exposure, windows of vulnerability and the environment [200, 232, 233]. A number of reviews have described inconsistencies in these findings $[200,233]$ thought to be due to methodological confounding of cocaine exposure with exposure to other drugs, lack of biochemical verification for exposure status and levels and lack of adequate control for demographic variables (such as prenatal care, SES and outof-home placement). Another possibility is that there may be inconsistencies in the findings because different pathophysiologies could result in different behavioral outcomes. Findings of an altered cortisol response to stimulation in cocaine-exposed infants [176-178], although limited, are consistent with our model that glucocorticoid-mediated (HPA) activation may be altered by in utero cocaine exposure, and could suggest specific neurobehavioral endophenotypes associated with this particular pathway in infants that would help interpret findings in the literature.

No doubt our model oversimplifies the human situation and describes one of many pathways that may be involved. Women who use cocaine during pregnancy typically use other substances [234], and we have not addressed the issue of polydrug use. However, the view of cocaine as a stressor could suggest that polydrug exposure be studied as cumulative stress. The model could have wider applicability and generalize to other substances including illicit (methamphetamine, heroine, marijuana) and legal (tobacco, alcohol) drugs of abuse, abuse of prescription medication (e.g. OxyContin, Vicodin) and psychotropic medication such as SSRI taken during pregnancy for the treatment of depression. The model may also be relevant beyond just drug effects to other perinatal stressors. Poor nutrition in these women is an additional important factor that can cause fetal growth restriction, in addition to the placental vascular mechanisms described above. Factors such as poverty, domestic violence and comorbid psychopathology, all of which have been documented in these women, may also affect fetal development. Again these factors could suggest the applicability of cumulative stress models.

Finally, the model may also be relevant for other outcomes, including obesity. Compulsive disorders such as drug addiction, obesity and gambling have been described as part of a 'reward deficiency syndrome' [235]. 
Obese individuals show reduced brain dopamine $\mathrm{D}_{2}$ availability [236] raising the interesting possibility that drug addiction and pathological eating could represent 2 forms of compulsive behavior as a means to compensate for decreased activation of dopamine circuits. Prenatal cocaine exposure could also lead to compulsive behavior and obesity through this neurochemical pathway (our first pathophysiology of cocaine) by which prenatal cocaine exposure could lead to compulsive behavior which in turn leads to obesity. Our 'cocaine stress' model suggests that neuroendocrine changes in the intrauterine environment could also lead to compulsive behavior and obesity. In addition, the idea that neuroendocrine mechanisms are related to physiological and metabolic changes that lead to the fetal origins of adult disease [61] suggests a direct effect between prenatal cocaine exposure and obesity. Some support for this comes from our work showing that prenatal cocaine exposure was related to higher body mass index (BMI) at 9 years of age [237]. Higher BMI was also related to higher blood pressure in these children, suggesting that the effects of cocaine on blood pressure are mediated through BMI.

The cascade of events that initiates the repeated activation of biological stress-response systems or allostatic load [116] begins as fetal reprogramming of the neuroendocrine system due to drugs and other intrauterine stressors, leading to infant behavioral dysregulation and poor behavioral control and emotion regulation during childhood. The toll that allostatic load takes on the HPA system further affects the vulnerable adolescent brain and leads to phenotypes that confer vulnerability to substance use in adolescence.

\section{References}

1 Shurtleff D, Ferre S: Sponsor's foreword (editorial). ScientificWorldJournal 2007;7 (suppl 2):1-3.

$>2$ Schenker S, Yang Y, Johnson RF, et al: The transfer of cocaine and its metabolites across the term human placenta. Clin Pharmacol Ther 1993;53:329-339.

3 Gawin FH, Ellinwood EH Jr: Cocaine and other stimulants: actions, abuse, and treatment. N Engl J Med 1988;318:1173-1182.

4 Wise R: Neural Mechanisms of the Reinforcing Action of Cocaine. NIDA Research Monograph 50. Rockville, National Institute on Drug Abuse, 1984, pp 15-33.

5 Goodman L: The Pharmacological Basis of Therapeutics. New York, MacMillan, 1985.

6 Bzoskie L, Blount L, Kashiwai K, Humme J, Padbury J: The contribution of transporterdependent uptake to fetal catecholamine clearance. Biol Neonate 1997;71:102-110.

7 Lau C, Burke S, Slotkin T: Maturation of sympathetic neurotransmission in the rat heart. IX. Development of transsynaptic regulation of cardiac adrenergic sensitivity. J Pharmacol Exp Ther 1982;223:675-680.

$>8$ Padbury JF, Ludlow JK, Humme JA, Agata Y: Metabolic clearance and plasma appearance rates of catecholamines in preterm and term fetal sheep. Pediatr Res 1986;20:992-995.

$>9$ Stein H, Oyama K, Martinez A, Chappell B, Padbury J: Plasma epinephrine appearance and clearance rates in fetal and newborn sheep. Am J Physiol 1993;265(part 2):R756R760.

10 NIDA: Mechanisms of Cocaine Abuse and Toxicity. Rockville, National Institute on Drug Abuse, 1988.
Kalivas PW, Duffy P, DuMars LA, Skinner C: Behavioral and neurochemical effects of acute and daily cocaine administration in rats. J Pharmacol Exp Ther 1988;245:485-492.

12 Peris J, Boyson SJ, Cass WA, et al: Persistence of neurochemical changes in dopamine systems after repeated cocaine administration. J Pharmacol Exp Ther 1990;253:38-44.

13 Kalivas P, Duffy P: Effect of acute and daily cocaine treatment on extracellular dopamine in the nucleus accumbens. Synapse 1990;5:48-58.

14 Steketee JD, Striplin CD, Murray TF, Kalivas PW: Possible role for G-proteins in behavioral sensitization to cocaine. Brain Res 1991; 545:287-291.

15 Arai S, Morita K, Kitayama S, et al: Chronic inhibition of the norepinephrine transporter in the brain participates in seizure sensitization to cocaine and local anesthetics. Brain Res 1993;964:83-90.

16 Mead AN, Rocha BA, Donovan DM, Katz JL: Intravenous cocaine induced-activity and behavioural sensitization in norepinephrine-, but not dopamine-transporter knockout mice. Eur J Neurosci 2002;16:514-520.

17 Kreek MJ: Cocaine, dopamine and the endogenous opioid system. J Addict Dis 1996; 15:73-96.

18 Shippenberg TS, Rea W: Sensitization to the behavioral effects of cocaine: modulation by dynorphin and kappa-opioid receptor agonists. Pharmacol Biochem Behav 1997;57: 449-455.

19 White FJ, Hu XT, Zhang XF, Wolf ME: Repeated administration of cocaine or amphetamine alters neuronal responses to glutamate in the mesoaccumbens dopamine system. J Pharmacol Exp Ther 1995;273: $445-454$.
20 Ye JH, Liu PL, Wu WH, McArdle JJ: Cocaine depresses GABAA current of hippocampal neurons. Brain Res 1997;770(1-2):169-175.

21 Garg UC, Turndorf H, Bansinath M: Effect of cocaine on macromolecular syntheses and cell proliferation in cultured glial cells. Neuroscience 1993;57:467-472.

-22 Nassogne MC, Evrard P, Courtoy PJ: Selective neuronal toxicity of cocaine in embryonic mouse brain cocultures. Proc Natl Acad Sci USA 1995;92:11029-11033.

23 Nassogne MC, Evrard P, Courtoy PJ: Selective direct toxicity of cocaine on fetal mouse neurons: teratogenic implications of neurite and apoptotic neuronal loss. Ann NY Acad Sci 1998;846:51-68.

24 Akbari HM, Whitaker-Azmitia PM, Azmitia EC: Prenatal cocaine decreases the trophic factor S-100 beta and induced microcephaly: reversal by postnatal 5-HT1A receptor agonist. Neurosci Lett 1994;170:141-144.

25 Gressens P, Gofflot F, Van Maele-Fabry G, et al: Early neurogenesis and teratogenesis in whole mouse embryo cultures: histochemical, immunocytological and ultrastructural study of the premigratory neuronal-glial units in normal mouse embryo and in mouse embryos influenced by cocaine and retinoic acid. J Neuropathol Exp Neurol 1992;51: 206-219.

26 Gressens P, Kosofsky BE, Evrard P: Cocaineinduced disturbances of corticogenesis in the developing murine brain. Neurosci Lett 1992;140:113-116. 
27 Yablonsky-Alter E, Gleser I, Carter C, Juvan M: Effects of prenatal cocaine treatment on postnatal development of neocortex in white mice: immunocytochemistry of calbindinand paralbumin-positive populations of GABAergic neurons. Soc Neurosci Abstr 1992; 18:367.

-28 Steiner H, Gerfen CR: Dynorphin opioid inhibition of cocaine-induced, $\mathrm{D}_{1}$ dopamine receptor-mediated immediate-early gene expression in the striatum. J Comp Neurol 1995; 353:200-212.

-29 Steiner H, Gerfen CR: Cocaine-induced $c$-fos messenger RNA is inversely related to dynorphin expression in striatum. J Neurosci 1993;13:5066-5081.

-30 Bhat RV, Baraban JM: Activation of transcription factor genes in striatum by cocaine: role of both serotonin and dopamine systems. J Pharmacol Exp Ther 1993;267:496505.

31 Lester B, Kosofsky B: Effects of drugs of abuse on brain development; in Charney D, Nestler E (eds): Neurobiology of Mental Illness, ed 3. New York, Oxford University Press, 2008.

- 32 al-Ghazali W, Chita SK, Chapman MG, Allan LD: Evidence of redistribution of cardiac output in asymmetrical growth retardation. Br J Obstet Gynaecol 1989;96:697-704.

- 33 Jensen A, Hohmann M, Kunzel W: Redistribution of fetal circulation during repeated asphyxia in sheep: effects on skin blood flow, transcutaneous $\mathrm{P}_{\mathrm{O}_{2}}$, and plasma catecholamines. J Dev Physiol 1987;9:41-55.

34 Naeye R: Disorders of the Placenta, Fetus and Neonate: Diagnosis and Clinical Significance. St. Louis, Mosby, 1992.

- 35 Jansson T: Responsiveness to norepinephrine of the vessels supplying the placenta of growth-retarded fetuses. Am J Obstet Gynecol 1988;158:1233-1237.

- 36 Jones CT, Robinson JS: Studies on experimental growth retardation in sheep: plasma catecholamines in fetuses with small placenta. J Dev Physiol 1983;5:77-87.

- 37 Lagercrantz H, Sjorquist B, Bremme K, Lunell N, Somell C: Catecholamine metabolites in amniotic fluid as indicators of intrauterine stress. Am J Obstet Gynecol 1980 136:1067-1070

- 38 Bassett JM, Hanson C: Catecholamines inhibit growth in fetal sheep in the absence of hypoxemia. Am J Physiol 1998;274(part 2) R1536-R1545.

- 39 Bzoskie L, Blount L, Kashiwai K, Humme J, Padbury J: Placental norepinephrine transporter development in the ovine fetus. Placenta 1997;18:65-70.

-40 Koegler SM, Seidler FJ, Spencer JR, Slotkin TA: Ischemia contributes to adverse effects of cocaine on brain development: suppression of ornithine decarboxylase activity in neonatal rat. Brain Res Bull 1991;27:829_ 834 .
41 Woods JR Jr, Plessinger MA, Clark KE: Effect of cocaine on uterine blood flow and fetal oxygenation. JAMA 1987;257:957-961.

42 Reviriego J, Fernandez-Alfonso MS, Marin J: Actions of vasoactive drugs on human placental vascular smooth muscle. Gen Pharmacol 1990;21:719-727.

43 Zhang L, Dyer DC: Characterization of alpha-adrenoceptors mediating contraction in isolated ovine umbilical vein. Eur J Pharmacol 1991;197:63-67.

44 Dyer DC: An investigation of the mechanism of potentiation by cocaine of responses to serotonin in sheep umbilical blood vessels. J Pharmacol Exp Ther 1970;175:571576

45 Nair X, Dyer DC: Responses of guinea pig umbilical vasculature to vasoactive drugs. Eur J Pharmacol 1974;27:294-304.

46 Fox SB, Khong TY: Lack of innervation of human umbilical cord: an immunohistological and histochemical study. Placenta 1990; 11:59-62.

47 Walker DW, McLean JR: Absence of adrenergic nerves in the human placenta. Nature 1971;229:344-345.

48 Kobayashi K, Morita S, Sawada H, et al: Targeted disruption of the tyrosine hydroxylase locus results in severe catecholamine depletion and perinatal lethality in mice. J Biol Chem 1995;270:27235-27243.

49 Zhou QY, Quaife CJ, Palmiter RD: Targeted disruption of the tyrosine hydroxylase gene reveals that catecholamines are required for mouse fetal development. Nature 1995;374: 640-643.

50 Thomas SA, Matsumoto AM, Palmiter RD: Noradrenaline is essential for mouse fetal development. Nature 1995;374:643-646.

51 Thomas SA, Palmiter RD: Examining adrenergic roles in development, physiology, and behavior through targeted disruption of the mouse dopamine beta-hydroxylase gene. Adv Pharmacol 1998:42:57-60.

52 Whitaker-Azmitia PM, Druse M, Walker P, Lauder JM: Serotonin as a developmental signal. Behav Brain Res 1996;73:19-29.

53 Yavarone MS, Shuey DL, Tamir H, Sadler TW, Lauder JM: Serotonin and cardiac morphogenesis in the mouse embryo. Teratology 1993;47:573-584.

54 Shuey DL, Sadler TW, Tamir H, Lauder JM: Serotonin and morphogenesis: transient expression of serotonin uptake and binding protein during craniofacial morphogenesis in the mouse. Anat Embryol (Berl) 1993;187: 75-85.

55 Choi DS, Ward SJ, Messaddeq N, Launay JM, Maroteaux L: 5-HT2B receptor-mediated serotonin morphogenetic functions in mouse cranial neural crest and myocardiac cells. Development 1997;124:1745-1755.

56 Church MW, Rauch HC: Prenatal cocaine exposure in the laboratory mouse: effects on maternal water consumption and offspring outcome. Neurotoxicol Teratol 1992;14:313319.
7 Fantel AG, Macphail BJ: The teratogenicity of cocaine. Teratology 1982;26:17-19.

58 Bauer CR, Langer JC, Shankaran S, et al: Acute neonatal effects of cocaine exposure during pregnancy. Arch Pediatr Adolesc Med 2005;159:824-834

- 59 Barker DJ, Osmond C, Rodin I, Fall CH, Winter PD: Low weight gain in infancy and suicide in adult life. BMJ 1995;311:1203.

60 Gluckman PD, Hanson MA: Living with the past: evolution, development, and patterns of disease. Science 2004;305:1733-1736.

61 Welberg LA, Seckl JR: Prenatal stress, glucocorticoids and the programming of the brain. J Neuroendocrinol 2001;13:113-128.

62 Barker D: Fetal programming of coronary heart disease. Trends Endocrinol Metab 2002;13:364-368.

63 McMillen IC, Robinson JS: Developmental origins of the metabolic syndrome: prediction, plasticity, and programming. Physiol Rev 2005;85:571-633.

64 Barker DJ: The fetal origins of adult hypertension. J Hypertens Suppl 1992;10:S39S44.

65 Barker DJ, Osmond C, Golding J, Kuh D, Wadsworth ME: Growth in utero, blood pressure in childhood and adult life, and mortality from cardiovascular disease. BMJ 1989;298:564-567.

66 Falkner B: Birth weight as a predictor of future hypertension. Am J Hypertens 2002;15: S43-S45.

67 Rich-Edwards JW, Colditz GA, Stampfer MJ, et al: Birthweight and the risk for type 2 diabetes mellitus in adult women. Ann Intern Med 1999;130(part 1):278-284.

68 Stein CE, Fall CH, Kumaran K, Osmond C, Cox V, Barker DJ: Fetal growth and coronary heart disease in south India. Lancet 1996; 348:1269-1273.

69 Sallout B, Walker M: The fetal origin of adult diseases. J Obstet Gynaecol 2003;23:555560.

70 Phillips D, Barker D, Hales C, Hirst S, Osmond C: Thinness at birth and insulin resistance in adult life. Diabetologia 1994;37:150 154

71 Ong KK, Dunger DB: Birth weight, infant growth and insulin resistance. Eur J Endocrinol 2004;151(suppl 3):U131-U139.

72 Hales CN, Barker DJ, Clark PM, et al: Fetal and infant growth and impaired glucose tolerance at age 64. BMJ 1991;303:1019-1022.

73 Wals M, Reichart CG, Hillegers MH, et al Impact of birth weight and genetic liability on psychopathology in children of bipolar parents. J Am Acad Child Adolesc Psychiatry 2003;42:1116-1121.

74 Allin M, Rooney M, Cuddy M, et al: Personality in young adults who are born preterm. Pediatrics 2006;117:309-316.

75 Thompson C, Syddall H, Rodin I, Osmond C, Barker DJ: Birth weight and the risk of depressive disorder in late life. Br J Psychiatry 2001;179:450-455. 
76 Gale CR, Martyn CN: Birth weight and later risk of depression in a national birth cohort. Br J Psychiatry 2004;184:28-33.

-77 Matthews SG: Antenatal glucocorticoids and the developing brain: mechanisms of action. Semin Neonatol 2001;6:309-317.

-78 Slotkin TA, Orband-Miller L, Queen KL, Whitmore WL, Seidler FJ: Effects of prenatal nicotine exposure on biochemical development of rat brain regions: maternal drug infusions via osmotic minipumps. J Pharmacol Exp Ther 1987;240:602-611.

79 Williams MT, Hennessy MB, Davis HN: Stress during pregnancy alters rat offspring morphology and ultrasonic vocalizations. Physiol Behav 1998;63:337-343.

80 Barbazanges A, Piazza PV, Le Moal M, Maccari S: Maternal glucocorticoid secretion mediates long-term effects of prenatal stress. J Neurosci 1996;16:3943-3949.

81 Henry C, Kabbaj M, Simon H, Le Moal M, Maccari S: Prenatal stress increases the hypothalamo-pituitary-adrenal axis response in young and adult rats. J Neuroendocrinol 1994;6:341-345.

-82 Maccari S, Piazza PV, Kabbaj M, Barbazanges A, Simon H, Le Moal M: Adoption reverses the long-term impairment in glucocorticoid feedback induced by prenatal stress. J Neurosci 1995;15(part 1):110-116.

$\$ 83$ Vallee M, Mayo W, Dellu F, Le Moal M, Simon H, Maccari S: Prenatal stress induces high anxiety and postnatal handling induces low anxiety in adult offspring: correlation with stress-induced corticosterone secretion. J Neurosci 1997;17:2626-2636.

$\checkmark 84$ Fride E, Dan Y, Feldon J, Halevy G, Weinstock M: Effects of prenatal stress on vulnerability to stress in prepubertal and adult rats. Physiol Behav 1986;37:681-687.

-85 Pfister HP, Muir JL: Prenatal exposure to predictable and unpredictable novelty stress and oxytocin treatment affects offspring development and behavior in rats. Int J Neurosci 1992;62:227-241.

86 Poltyrev T, Keshet GI, Kay G, Weinstock M: Role of experimental conditions in determining differences in exploratory behavior of prenatally stressed rats. Dev Psychobiol 1996;29:453-462.

87 Wakshlak A, Weinstock M: Neonatal handling reverses behavioral abnormalities induced in rats by prenatal stress. Physiol Behav 1990;48:289-292.

-88 Takahashi LK, Haglin C, Kalin NH: Prenatal stress potentiates stress-induced behavior and reduces the propensity to play in juvenile rats. Physiol Behav 1992;51:319-323.

89 Takahashi LK, Turner JG, Kalin NH: Prenatal stress alters brain catecholaminergic activity and potentiates stress-induced behavior in adult rats. Brain Res 1992;574:131137.
0 Lambert KG, Kinsley CH, Jones HE, Klein SL, Peretti SN, Stewart KM: Prenatal stress attenuates ulceration in the activity stress paradigm. Physiol Behav 1995;57:989-994.

-91 Weller A, Glaubman H, Yehuda S, Caspy T, Ben-Uria Y: Acute and repeated gestational stress affect offspring learning and activity in rats. Physiol Behav 1988;43:139-143.

$\checkmark 92$ Hayashi A, Nagaoka M, Yamada K, Ichitani Y, Miake Y, Okado N: Maternal stress induces synaptic loss and developmental disabilities of offspring. Int J Dev Neurosci 1998;16:209-216.

$\checkmark 93$ Szuran T, Zimmermann E, Welzl H: Water maze performance and hippocampal weight of prenatally stressed rats. Behav Brain Res 1994;65:153-155.

$\$ 94$ Vallee M, MacCari S, Dellu F, Simon H, Le Moal M, Mayo W: Long-term effects of prenatal stress and postnatal handling on agerelated glucocorticoid secretion and cognitive performance: a longitudinal study in the rat. Eur J Neurosci 1999;11:2906-2916.

$\$ 95$ Meaney M, Seckl J: Glucocorticoid programming. Ann NY Acad Sci 2004;1032: 63-84.

$\$ 96$ Roughton EC, Schneider ML, Bromley LJ, Coe CL: Maternal endocrine activation during pregnancy alters neurobehavioral state in primate infants. Am J Occup Ther 1998;52:90-98.

97 Schneider M, Moore C, Kraemer G: Moderate level alcohol during pregnancy, prenatal stress, or both and limbic-hypothalamicpituitary-adrenocortical axis response to stress in rhesus monkeys. Child Dev 2004; 75:96-109.

$\$ 98$ Schneider ML: Prenatal stress exposure alters postnatal behavioral expression under conditions of novelty challenge in rhesus monkey infants. Dev Psychobiol 1992;25: 529-540.

$\$ 99$ McEwen BS: Glucocorticoid-biogenic amine interactions in relation to mood and behavior. Biochem Pharmacol 1987;36: 1755-1763.

100 Maes M, Meltzer HY, D’Hondt P, Cosyns P, Blockx P: Effects of serotonin precursors on the negative feedback effects of glucocorticoids on hypothalamic-pituitary-adrenal axis function in depression. Psychoneuroendocrinology 1995;20:149-167.

101 Meador-Woodruff JH, Greden JF, Grunhaus L, Haskett RF: Severity of depression and hypothalamic-pituitary-adrenal axis dysregulation: identification of contributing factors. Acta Psychiatr Scand 1990;81: 364-371.

102 Nemeroff CB, Widerlov E, Bissette G, et al: Elevated concentrations of CSF corticotropin-releasing factor-like immunoreactivity in depressed patients. Science 1984;226: 1342-1344.

103 van Praag HM: Depression. Lancet 1982;2: 1259-1264.
104 Wadhwa PD, Garite TJ, Porto M, et al: Placental corticotropin-releasing hormone (CRH), spontaneous preterm birth, and fetal growth restriction: a prospective investigation. Am J Obstet Gynecol 2004;191: 1063-1069.

105 Wadhwa PD, Sandman CA, Garite TJ: The neurobiology of stress in human pregnancy: implications for prematurity and development of the fetal central nervous system. Prog Brain Res 2001;133:131-142.

106 Lou HC, Hansen D, Nordentoft M, et al: Prenatal stressors of human life affect fetal brain development. Dev Med Child Neurol 1994;36:826-832.

107 van Os J, Selten J: Prenatal exposure to maternal stress and subsequent schizophrenia. Br J Psychiatry 1998;172:324-326.

108 Field T: Stress and coping from pregnancy through the postnatal period; in Cummings EG, Green AL, Karraker KH (eds): Life-Span Developmental Psychology: Perspectives on Stress and Coping. Hillsdale, Lawrence Erlbaum Associates, 1991, pp 45 59.

109 Huizink AC, Robles de Medina PG, Mulder EJ, Visser GH, Buitelaar JK: Stress during pregnancy is associated with developmental outcome in infancy. J Child Psychol Psychiatry 2003;44:810-818.

110 Levy-Shiff R, Dimitrovsky L, Shulman S, et al: Cognitive appraisals, coping strategies, and support resources as correlates of parenting and infant development. Dev Psychobiol 1998;34:1417-1427.

111 Meijer A: Child psychiatric sequelae of maternal war stress. Acta Psychiatr Scand 1985;72:505-511.

112 Stott DH: Follow-up study from birth of the effects of prenatal stresses. Dev Med Child Neurol 1973;15:770-787.

113 Ward AJ: Prenatal stress and childhood psychopathology. Child Psychiatry Hum Dev 1991;22:97-110.

114 DePietro J: The role of prenatal maternal stress in child development. Curr Dir Psychol Sci 2004;13:71-74.

115 McEwen BS: Protective and damaging effects of stress mediators. N Engl J Med 1998; 338:171-179.

116 McEwen BS: Early life influences on lifelong patterns of behavior and health. Ment Retard Dev Disabil Res Rev 2003;9:149154.

117 Nguyen TT, Tseng YT, McGonnigal B, et al: Placental biogenic amine transporters: in vivo function, regulation and pathobiological significance. Placenta 1999;20:3-11.

118 Meyer JS: Biochemical effects of corticosteroids on neural tissues. Physiol Rev 1985; 65:946-1020.

119 Lopez Bernal A, Craft IL: Corticosteroid metabolism in vitro by human placenta, fetal membranes and decidua in early and late gestation. Placenta 1981;2:279-285. 
120 Benediktsson R, Lindsay RS, Noble J, Seckl 132 Sarkar S, Tsai SW, Nguyen TT, Plevyak M, JR, Edwards CR: Glucocorticoid exposure in utero: new model for adult hypertension. Lancet 1993;341:339-341.

-121 Murphy VE, Zakar T, Smith R, Giles WB, Gibson PG, Clifton VL: Reduced 11betahydroxysteroid dehydrogenase type 2 activity is associated with decreased birth weight centile in pregnancies complicated by asthma. J Clin Endocrinol Metab 2002; 87:1660-1668.

122 Stewart P, Roberson F, Mason J: Type 2 11hydroxysteroid dehydrogenase messenger RNA and activity in human placenta and fetal membranes: its relationship to birth weight and putative role in fetal steroidogenesis. J Clin Endocrinol Metab 1995;80: 885-890.

$\checkmark 123$ McTernan CL, Draper N, Nicholson H, et al: Reduced placental 11beta-hydroxysteroid dehydrogenase type $2 \mathrm{mRNA}$ levels in human pregnancies complicated by intrauterine growth restriction: an analysis of possible mechanisms. J Clin Endocrinol Metab 2001;86:4979-4983.

-124 Shams M, Kilby MD, Somerset DA, et al: 11Beta-hydroxysteroid dehydrogenase type 2 in human pregnancy and reduced expression in intrauterine growth restriction. Hum Reprod 1998;13:799-804.

-125 Dave-Sharma S, Wilson R, Harbison M: Extensive personal experience: examination of genotype and phenotype relationships in 14 patients with apparent mineralocorticoid excess. J Clin Endocrinol Metab 1998;83:2244-2254.

-126 Seckl JR, Cleasby M, Nyirenda MJ: Glucocorticoids, 11beta-hydroxysteroid dehydrogenase, and fetal programming. Kidney Int 2000;57:1412-1417.

- 127 Edwards CR, Benediktsson R, Lindsay RS, Seckl JR: Dysfunction of placental glucocorticoid barrier: link between fetal environment and adult hypertension? Lancet 1993;341:355-357.

-128 Seckl JR: Glucocorticoids, feto-placental 11 beta-hydroxysteroid dehydrogenase type 2, and the early life origins of adult disease. Steroids 1997;62:89-94.

129 Gould E, Woolley CS, Cameron HA, Daniels DC, McEwen BS: Adrenal steroids regulate postnatal development of the rat dentate gyrus. II. Effects of glucocorticoids and mineralocorticoids on cell birth. J Comp Neurol 1991;313:486-493.

130 Gould E, Woolley CS, McEwen BS: Adrenal steroids regulate postnatal development of the rat dentate gyrus. I. Effects of glucocorticoids on cell death. J Comp Neurol 1991; 313:479-485.

131 Bohn MC: Granule cell genesis in the hippocampus of rats treated neonatally with hydrocortisone. Neuroscience 1980;5: 2003-2012. Padbury JF, Rubin LP: Inhibition of placental 11beta-hydroxysteroid dehydrogenase type 2 by catecholamines via alpha-adrenergic signaling. Am J Physiol Regul Integr Comp Physiol 2001;281:R1966-R1974.

133 Bzoskie L, Yen J, Tseng YT, Blount L, Kashiwai K, Padbury JF: Human placental norepinephrine transporter mRNA: expression and correlation with fetal condition at birth. Placenta 1997;18:205-210.

134 Bottalico B, Larsson I, Brodszki J, et al: Norepinephrine transporter (NET), serotonin transporter (SERT), vesicular monoamine transporter (VMAT2) and organic cation transporters (OCT1, 2 and EMT) in human placenta from pre-eclamptic and normotensive pregnancies. Placenta 2004; 25:518-529.

135 Jacob S, Moley KH: Gametes and embryo epigenetic reprogramming affect developmental outcome: implication for assisted reproductive technologies. Pediatr Res 2005;58:437-446.

136 Colvis CM, Pollock JD, Goodman RH, et al: Epigenetic mechanisms and gene networks in the nervous system. J Neurosci 2005;25: 10379-10389.

137 Oberlander TF, Weinberg J, Papsdorf M, Grunau R, Misri S, Devlin AM: Prenatal exposure to maternal depression, neonatal methylation of human glucocorticoid receptor gene (NR3C1) and infant cortisol stress responses. Epigenetics 2008;3:97106.

138 Kumar A, Choi K, Renthal W, et al: Chromatin remodeling is a key mechanism underlying cocaine-induced plasticity in striatum. Neuron 2005;48:303-314.

139 Loeber R, Burke JD, Lahey BB, Winters A, Zera M: Oppositional defiant and conduct disorder: a review of the past 10 years, part I. J Am Acad Child Adolesc Psychiatry 2000;39:1468-1484.

140 Hawkins JD, Graham JW, Maguin E, Abbott R, Hill KG, Catalano RF: Exploring the effects of age of alcohol use initiation and psychosocial risk factors on subsequent alcohol misuse. J Stud Alcohol 1997;58:280290.

141 Ellickson PL, Tucker JS, Klein DJ: High-risk behaviors associated with early smoking: results from a 5-year follow-up. J Adolesc Health 2001;28:465-473.

142 Tarter R, Vanyukov M, Giancola P, et al: Etiology of early age onset substance use disorder: a maturational perspective. Dev Psychopathol 1999;11:657-683.

143 Brook JS, Whiteman MM, Finch S: Childhood aggression, adolescent delinquency, and drug use: a longitudinal study. J Genet Psychol 1992;153:369-383.
144 Blackson TC, Butler T, Belsky J, Ammerman RT, Shaw DS, Tarter RE: Individual traits and family contexts predict sons' externalizing behavior and preliminary relative risk ratios for conduct disorder and substance use disorder outcomes. Drug Alcohol Depend 1999;56:115-131.

145 Chassin L, Barrera MJ: Substance use escalation and substance use restraint among adolescent children of alcoholics. Psychol Addict Bahav 1993;7:3-20.

146 Tarter RE, Blackson T, Brigham J, Moss H, Caprara GV: The association between childhood irritability and liability to substance use in early adolescence: a 2-year follow-up study of boys at risk for substance abuse. Drug Alcohol Depend 1995;39:253261.

147 Clark DB, Parker AM, Lynch KG: Psychopathology and substance-related problems during early adolescence: a survival analysis. J Clin Child Psychol 1999;28:333-341.

148 Aytaclar S, Tarter RE, Kirisci L, Lu S: Association between hyperactivity and executive cognitive functioning in childhood and substance use in early adolescence. J Am Acad Child Adolesc Psychiatry 1999; 38:172-178

149 Giancola P, Martin C, Tarter R, et al: Executive cognitive functioning and aggressive behavior in preadolescent boys at high risk for substance abuse. J Stud Alcohol 1996;57:352-359.

150 Shoal G, Giancola P: Executive cognitive functioning, negative affectivity, and drug use in adolescent boys with and without a family history of a substance use disorder. J Child Adolesc Subst Abuse 2001;10:111121.

151 Tarter RE, Kirisci L, Mezzich A, et al: Neurobehavioral disinhibition in childhood predicts early age at onset of substance use disorder. Am J Psychiatry 2003;160:10781085.

152 Volkow ND, Li TK: Drugs and alcohol: treating and preventing abuse, addiction and their medical consequences. Pharmacol Ther 2005;108:3-17.

153 Sowell ER, Thompson PM, Toga AW: Mapping changes in the human cortex throughout the span of life. Neuroscientist 2004;10: 372-392.

154 Sowell ER, Thompson PM, Peterson BS, et al: Mapping cortical gray matter asymmetry patterns in adolescents with heavy prenatal alcohol exposure. Neuroimage 2002; 17:1807-1819.

155 Giedd J: Brain development. IX. Human brain growth. Am J Psychiatry 1999;156:4.

156 Paus T, Zijdenbos A, Worsley K, et al: Structural maturation of neural pathways in children and adolescents: in vivo study. Science 1999;283:1908-1911. 
157 Gogtay N, Giedd JN, Lusk L, et al: Dynam- 172 McEwen BS: Glucocorticoids, depression, ic mapping of human cortical development during childhood through early adulthood. Proc Natl Acad Sci USA 2004;101:81748179.

158 Bauer LO, Hesselbrock VM: P300 decrements in teenagers with conduct problems: implications for substance abuse risk and brain development. Biol Psychiatry 1999; 46:263-272.

159 Giancola P, Tarter R: Executive cognitive functioning and risk for substance abuse. Psychol Sci 1999; 10:203-205.

160 Schweinsburg AD, Paulus MP, Barlett VC, et al: An fMRI study of response inhibition in youths with a family history of alcoholism. Ann NY Acad Sci 2004;1021:391-394.

161 Fuster JM: Executive frontal functions. Exp Brain Res 2000;133:66-70.

$\checkmark 162$ Chambers RA, Taylor JR, Potenza MN: Developmental neurocircuitry of motivation in adolescence: a critical period of addiction vulnerability. Am J Psychiatry 2003; 160:1041-1052.

163 Spear L: Neurobehavioral changes in adolescence. Curr Dir Psychol Sci 2000;9:111114.

164 Romeo RD, McEwen BS: Stress and the adolescent brain. Ann NY Acad Sci 2006; 1094:202-214.

165 McEwen BS, De Kloet ER, Rostene W: Adrenal steroid receptors and actions in the nervous system. Physiol Rev 1986;66:11211188.

166 Meaney MJ, Aitken DH: [3H]Dexamethasone binding in rat frontal cortex. Brain Res 1985;328:176-180.

$\checkmark 167$ Diorio D, Viau V, Meaney MJ: The role of the medial prefrontal cortex (cingulate gyrus) in the regulation of hypothalamic-pituitary-adrenal responses to stress. J Neurosci 1993;13:3839-3847.

168 Sanchez MM, Young LJ, Plotsky PM, Insel TR: Distribution of corticosteroid receptors in the rhesus brain: relative absence of glucocorticoid receptors in the hippocampal formation. J Neurosci 2000;20:46574668.

-169 Patel PD, Lopez JF, Lyons DM, Burke S, Wallace M, Schatzberg AF: Glucocorticoid and mineralocorticoid receptor mRNA expression in squirrel monkey brain. J Psychiatr Res 2000;34:383-392.

170 Paule MG, Gillam MP, Allen RR, Chelonis JJ: Effects of chronic in utero exposure to cocaine on behavioral adaptability in rhesus monkey offspring when examined in adulthood. Ann NY Acad Sci 2000;914: 412-417.

171 Chelonis JJ, Gillam MP, Paule MG: The effects of prenatal cocaine exposure on reversal learning using a simple visual discrimination task in rhesus monkeys. Neurotoxicol Teratol 2003;25:437-446. and mood disorders: structural remodeling in the brain. Metabolism 2005;54(suppl 1):20-23.

173 Isgor C, Kabbaj M, Akil H, Watson SJ: Delayed effects of chronic variable stress during peripubertal-juvenile period on hippocampal morphology and on cognitive and stress axis functions in rats. Hippocampus 2004;14:636-648.

174 Radley JJ, Rocher AB, Miller M, et al: Repeated stress induces dendritic spine loss in the rat medial prefrontal cortex. Cereb Cortex 2006;16:313-320.

175 Gunnar M, Prudhomme-White B: Salivary cortisol measures in infant and child assessment; in Twarog-Singer L, Zeskind PS (eds): Biobehavioral Assessment of the Infant. New York, Guilford Press, 2001.

176 Magnano CL, Gardner JM, Karmel BZ: Differences in salivary cortisol levels in cocaine-exposed and noncocaine-exposed NICU infants. Dev Psychobiol 1992;25:93103.

177 Jacobson SW, Bihun JT, Chiodo LM: Effects of prenatal alcohol and cocaine exposure on infant cortisol levels. Dev Psychopathol 1999;11:195-208.

178 Scafidi FA, Field TM, Wheeden A, et al: Cocaine-exposed preterm neonates show behavioral and hormonal differences. Pediatrics 1996;97(part 1):851-855.

179 Harvey JA: Cocaine effects on the developing brain: current status. Neurosci Biobehav Rev 2004;27:751-764.

180 Mayes LC: Developing brain and in utero cocaine exposure: effects on neural ontogeny. Dev Psychopathol 1999;11:685-714.

181 Lester BM, Tronick EZ, LaGasse L, et al: The maternal lifestyle study: effects of substance exposure during pregnancy on neurodevelopmental outcome in 1-month-old infants. Pediatrics 2002;110:1182-1192.

182 Lester BM, Lagasse L, Seifer R, et al: The Maternal Lifestyle Study (MLS): effects of prenatal cocaine and/or opiate exposure on auditory brain response at one month. J Pediatr 2003;142:279-285.

183 Miller-Loncar C, Lester BM, Seifer R, et al: Predictors of motor development in children prenatally exposed to cocaine. Neurotoxicol Teratol 2005;27:213-220.

184 Sheinkopf S, Lester B, LaGasse L, et al: Neonatal irritability, prenatal substance exposure, and later parenting stress. J Pediatr Psychol 2005;31:27-40.

185 Tronick EZ, Messinger DS, Weinberg MK, et al: Cocaine exposure is associated with subtle compromises of infants' and mothers' social-emotional behavior and dyadic features of their interaction in the face-toface still-face paradigm. Dev Psychol 2005; 41:711-722. ment status in children prenatally exposed to cocaine and other substances. Child Dev 2004;75:850-868.
186 Seifer R, LaGasse LL, Lester B, et al: Attach-
187 Bendersky M, Lewis M: Arousal modulation in cocaine-exposed infants. Dev Psychol 1998;34:555-564.

188 DiPietro J, Suess P, Wheeler J, Smouse P, Newlin D: Reactivity and regulation in cocaine-exposed neonates. Infant Behav Dev 1995; 18:407-414.

189 Gingras JL, O’Donnell KJ, Hume RF: Maternal cocaine addiction and fetal behavioral state. I. A human model for the study of sudden infant death syndrome. Med Hypotheses 1990;33:227-230.

190 Gingras JL, O’Donnell KJ: State control in the substance-exposed fetus. I. The fetal neurobehavioral profile: an assessment of fetal state, arousal, and regulation competency. Ann NY Acad Sci 1998;846:262276.

-191 Mayes LC, Bornstein MH, Chawarska K, Granger RH: Information processing and developmental assessments in 3-month-old infants exposed prenatally to cocaine. Pediatrics 1995;95:539-545.

192 Regalado M, Schechtman V, del Angel A, Bean X: Sleep disorganization in cocaineexposed neonates. Infant Behav Dev 1995; 18:319-327.

193 Regalado MG, Schechtman VL, Del Angel AP, Bean XD: Cardiac and respiratory patterns during sleep in cocaine-exposed neonates. Early Hum Dev 1996;44:187-200.

194 Susman EJ: Psychobiology of persistent antisocial behavior: stress, early vulnerabilities and the attenuation hypothesis. Neurosci Biobehav Rev 2006;30:376-389.

195 Gold PW, Chrousos GP: Organization of the stress system and its dysregulation in melancholic and atypical depression: high vs. low $\mathrm{CRH} / \mathrm{NE}$ states. Mol Psychiatry 2002;7:254-275.

196 Richardson GA: Prenatal cocaine exposure: a longitudinal study of development. Ann NY Acad Sci 1998;846:144-152.

197 Bennett DS, Bendersky M, Lewis M: Children's intellectual and emotional-behavioral adjustment at 4 years as a function of cocaine exposure, maternal characteristics, and environmental risk. Dev Psychol 2002; 38:648-658.

198 Arendt RE, Short EJ, Singer LT, et al: Children prenatally exposed to cocaine: developmental outcomes and environmental risks at seven years of age. J Dev Behav Pediatr 2004;25:83-90.

199 LaGasse L, Lester B, Seifer R, et al: Prenatal cocaine exposure and cognitive development at school age. Pediatr Res 2004;55:69.

200 Lester BM, LaGasse LL, Seifer R: Cocaine exposure and children: the meaning of subtle effects. Science 1998;282:633-634.

201 Singer LT, Minnes S, Short E, et al: Cognitive outcomes of preschool children with prenatal cocaine exposure. JAMA 2004; 291:2448-2456.

202 Mentis M: In utero cocaine exposure and language development. Semin Speech Lang 1998;19:147-164, quiz 165. 
203 Bandstra ES, Vogel AL, Morrow CE, Xue L, Anthony JC: Severity of prenatal cocaine exposure and child language functioning through age seven years: a longitudinal latent growth curve analysis. Subst Use Misuse 2004;39:25-59.

204 Lewis BA, Singer LT, Short EJ, et al: Fouryear language outcomes of children exposed to cocaine in utero. Neurotoxicol Teratol 2004;26:617-627.

205 Bandstra ES, Morrow CE, Vogel AL, et al: Longitudinal influence of prenatal cocaine exposure on child language functioning. Neurotoxicol Teratol 2002;24:297-308.

-206 Morrow CE, Bandstra ES, Anthony JC, Ofir AY, Xue L, Reyes MB: Influence of prenatal cocaine exposure on early language development: longitudinal findings from four months to three years of age. J Dev Behav Pediatr 2003;24:39-50.

207 Loebstein R, Koren G: Pregnancy outcome and neurodevelopment of children exposed in utero to psychoactive drugs: the Motherisk experience. J Psychiatry Neurosci 1997; 22:192-196.

208 Noland JS, Singer LT, Short EJ, et al: Prenatal drug exposure and selective attention in preschoolers. Neurotoxicol Teratol 2005; 27:429-438.

209 Schroder MD, Snyder PJ, Sielski I, Mayes L: Impaired performance of children exposed in utero to cocaine on a novel test of visuospatial working memory. Brain Cogn 2004; 55:409-412.

-210 Bandstra ES, Morrow CE, Anthony JC, Accornero VH, Fried PA: Longitudinal investigation of task persistence and sustained attention in children with prenatal cocaine exposure. Neurotoxicol Teratol 2001;23: 545-559.

-211 Delaney-Black V, Covington C, Templin T, Ager J, Martier S, Sokol R: Prenatal cocaine exposure and child behavior. Pediatrics 1998;102(part 1):945-950.

-212 Delaney-Black V, Covington C, Templin T, et al: Teacher-assessed behavior of children prenatally exposed to cocaine. Pediatrics 2000;106:782-791.

213 Mayes L, Snyder PJ, Langlois E, Hunter N: Visuospatial working memory in schoolaged children exposed in utero to cocaine. Child Neuropsychol 2007;13:205-218.
214 Morrow CE, Culbertson JL, Accornero VH, Xue L, Anthony JC, Bandstra ES: Learning disabilities and intellectual functioning in school-aged children with prenatal cocaine exposure. Dev Neuropsychol 2006;30:905931.

215 Levine T, Liu J, Das A, et al: Effects of prenatal cocaine exposure on special education in school age children. Pediatrics 2008; 122:e83-e91.

216 Covington C, Nordstrom-Klee B, DelaneyBlack V, Templin T, Ager J, Sokol RJ: Development of an instrument to assess problem behavior in first grade students prenatally exposed to cocaine. Part II. Validation. Subst Abus 2001;22:217-233.

217 Linares TJ, Singer LT, Kirchner HL, et al: Mental health outcomes of cocaine-exposed children at 6 years of age. J Pediatr Psychol 2006;31:85-97.

218 Accornero VH, Morrow CE, Bandstra ES, Johnson AL, Anthony JC: Behavioral outcome of preschoolers exposed prenatally to cocaine: role of maternal behavioral health. J Pediatr Psychol 2002;27:259-269.

-219 Bada HS, Das A, Bauer CR, et al: Impact of prenatal cocaine exposure on child behavior problems through school age. Pediatrics 2007;119:e348-e359.

220 Savage J, Brodsky NL, Malmud E, Giannetta JM, Hurt H: Attentional functioning and impulse control in cocaine-exposed and control children at age ten years. J Dev Behav Pediatr 2005;26:42-47.

221 Wasserman GA, Kline JK, Bateman DA, et al: Prenatal cocaine exposure and schoolage intelligence. Drug Alcohol Depend 1998;50:203-210.

-222 Hurt H, Malmud E, Betancourt L, Brodsky NL, Giannetta J: A prospective evaluation of early language development in children with in utero cocaine exposure and in control subjects. J Pediatr 1997;130:310-312.

223 Pulsifer MB, Radonovich K, Belcher HM, Butz AM: Intelligence and school readiness in preschool children with prenatal drug exposure. Child Neuropsychol 2004;10:89101.

224 Warner TD, Behnke M, Eyler FD, et al: Diffusion tensor imaging of frontal white matter and executive functioning in cocaineexposed children. Pediatrics 2006;118: 2014-2024.

-225 Dow-Edwards DL, Benveniste H, Behnke $M$, et al: Neuroimaging of prenatal drug exposure. Neurotoxicol Teratol 2006;28:386402 .
226 Avants BB, Hurt H, Giannetta JM, et al: Effects of heavy in utero cocaine exposure on adolescent caudate morphology. Pediatr Neurol 2007;37:275-279.

227 Neyzi N, Quinn B, Kekatpure D, et al: Automated Segmentation of Brain Structures in a Pediatric Population with Prenatal Cocaine Exposure. San Diego, Society for Neuroscience, 2007.

228 Hurt H, Giannetta JM, Korczykowski M, et al: Functional magnetic resonance imaging and working memory in adolescents with gestational cocaine exposure. J Pediatr 2008;152:371-377.

229 Sheinkopf S, Lester B, Sanes J, et al: Functional MRI and response inhibition in children exposed to cocaine in utero. Dev Neurosci, in press.

230 Rao H, Wang J, Giannetta J, et al: Altered resting cerebral blood flow in adolescents with in utero cocaine exposure revealed by perfusion functional MRI. Pediatrics 2007; 120:e1245-e1254.

231 Smith LM, Chang L, Yonekura ML, et al: Brain proton magnetic resonance spectroscopy and imaging in children exposed to cocaine in utero. Pediatrics 2001;107:227231.

232 Wetherington C, Smeriglio V, Finnegan L: Behavioral Studies of Drug-Exposed Offspring: Methodological Issues in Human and Animal Research. NIDA Monograph Series 164. Rockville, National Institute on Drug Abuse, 1998.

233 Frank DA, Augustyn M, Knight WG, Pell T, Zuckerman B: Growth, development, and behavior in early childhood following prenatal cocaine exposure: a systematic review. JAMA 2001;285:1613-1625.

234 Lester BM, ElSohly M, Wright LL, et al: The Maternal Lifestyle Study: drug use by meconium toxicology and maternal self-report. Pediatrics 2001;107:309-317.

235 Blum K, Cull J, Braverman E, Comings D: Reward deficiency syndrome. Am Sci 1996; 84:132-145.

236 Wang GJ, Volkow ND, Logan J, et al: Brain dopamine and obesity. Lancet 2001;357: 354-357.

237 Shankaran S, Das A, Bada H, et al: Prenatal cocaine exposure predicts blood pressure at 9 years of age. Presented at the Pediatric Academic Society Annual Meeting, May 16th, 2005; Washington, DC. http://www. abstracts2view.com/pasall/view.php? $\mathrm{nu}=$ PAS5L1_694. 